\title{
Individualized intravenous thrombolytic strategy for acute ischemic stroke with large vessel occlusion on the era of mechanical thrombectomy: cases report
}

\author{
Pengfei Xing ${ }^{1}$ (D) Hongjian Shen ${ }^{1} \cdot$ Zifu Li $^{1} \cdot$ Pengfei Yang ${ }^{1} \cdot$ Yongwei Zhang ${ }^{1} \cdot$ Jianmin Liu $^{1}$
}

Received: 9 August 2018 / Accepted: 9 October 2019/Published online: 14 November 2019

(C) The Author(s) 2019

\begin{abstract}
Intravenous thrombolysis for acute ischemic stroke within $4.5 \mathrm{~h}$ after the onset of symptoms has become a standard therapy that is recommended by many trials and clinical guidelines. As on the era of mechanical thrombectomy for acute ischemic stroke with large vessel occlusions, whether intravenous thrombolysis (IVT) is still necessary, and how to choose the optimal dose are still controversy. Here, we reported two cases of acute ischemic stroke with large vessel occlusions that both achieved complete recanalization after IVT. Then, IVT was terminated in advance, and dynamic surveillance by DSA was performed to achieve individual treatment. However, both of the cases presented with hemorrhagic transformation. We analyzed the probable reasons and put forward thoughts from ourselves.
\end{abstract}

Keywords Intravenous thrombolysis $\cdot$ Mechanical thrombectomy $\cdot$ Ischemic stroke

\section{Introduction}

Intravenous thrombolysis (IVT) for acute ischemic stroke within $4.5 \mathrm{~h}$ after the onset of symptoms, using recombinant tissue-type plasminogen activator (rtPA) with the recommended dose of $0.9 \mathrm{mg} / \mathrm{kg}$, is a standard therapy and recommended by various trials and guidelines [1-3]. However, the

Pengfei Xing and Hongjian Shen contributed equally to this work.

Yongwei Zhang

zhangyongwei@163.com

$\triangle$ Jianmin Liu

Liu118@vip.163.com

Pengfei Xing

weixpfsmmu@163.com

Hongjian Shen

fox2shj@126.com

Zifu Li

zifuli2008@163.com

Pengfei Yang

15921196312@163.com

1 Department of Cerebrovascular Disease Center, Changhai Hospital, Second Military Medical University, No.168 Changhai Rd, Shanghai 200433, China appropriate dose is still being controversial considering the balance of effectiveness and safety. Some studies showed that low-dose rtPA was comparable with the standard-dose treatment in terms of effectiveness [4-7]. In contrast, someone indicated that standard-dose intravenous rtPA could achieve more favorable outcome without increasing the risk of symptomatic hemorrhage than low-dose rtPA [8]. Moreover, comparing with IVT, mechanical thrombectomy (MT) has been proved to be more effective for acute ischemic stroke with large vessel occlusion (AIS-LVO) due to the high rates of successful recanalization (modified TICI $2 \mathrm{~b}-3$ grades) [9-15]. The subgroup study of HERMES collaboration suggested that the effects favoring the intervention was significant in those not receiving intravenous alteplase [16]. Therefore, the major controversy is that whether it is necessary to perform IVT before MT for AIS-LVO within the thrombolytic time window. We reported two cases of AIS-LVO that was treated by only IVT, and the dose of intravenous rtPA was controlled individually according to their timely angiography results.

\section{Case 1}

A 67-year-old male presented with sudden left limbs deficit was admitted to our hospital at $33 \mathrm{~min}$ after symptom 
onset. Non-contrast head CT was performed immediately (multimodal CT scan was not available at that time) and revealed no intracranial hemorrhage but with high- density on the right middle cerebral artery (MCA) M1 segment (Fig. 1a). The National Institute of Health Stroke Scale (NIHSS) scored 14, and the patient was treated with IVT $(\mathrm{rtPA} 0.9 \mathrm{mg} / \mathrm{kg} \times 78 \mathrm{~kg}$ ) that followed by digital subtraction angiography (DSA). The first image of DSA showed that the right MCA M1 segment was occluded with a score of American Society of Interventional and Therapeutic Neuroradiology collateral grading (ACG) system 3 (Fig. $1 \mathrm{~b}$ and c). However, the M1 segment was recanalization 6 min after the first DSA image, and the residual thrombus had immigrated to the M2 segment (Fig. 1d and e). Fortunately, the vessel achieved complete recanalization after another $5 \mathrm{~min}$ without any endovascular treatment in the whole process (Fig. 1f). Therefore, IVT was terminated in advance with a total dose of $42 \mathrm{mg}$ ( $3 / 5$ standard-dose, $0.54 \mathrm{mg} / \mathrm{kg}$ individually). The door-to-needle time (DNT), door-to-puncture time, onset-to-needle time, and onset-to-reperfusion time were $30 \mathrm{~min}, 58 \mathrm{~min}, 63 \mathrm{~min}$, and $106 \mathrm{~min}$, respectively.
Immediate result of Dyna-CT scan (Artis zee biplane, Siemens, Germany) confirmed no intracranial hemorrhage (Fig. 1g), and the NIHSS score decreased to 1 at $24 \mathrm{~h}$. However, asymptomatic intracranial hemorrhage in the infarction area was detected by the non-contrast CT imaging at $24 \mathrm{~h}$, with class 3 of the Heidelberg Bleeding Classification [17] (Fig. 1h). Finally, the modified Rankin Score (mRS) of the patient at 90 days was 0.

\section{Case 2}

An 80-year-old male presented with sudden slurred speech and weakness of the right limbs was sent to our hospital at 102 min after the symptom onset. The preprocedure NIHSS score was 14 and a multimodal CT was performed. There was no intracranial hemorrhage and significant infarcted territory on non-contrast CT imaging. However, the CT angiography showed occlusion of the upper branch of left MCA M1 segment with lower perfusion that was revealed by cerebral blood volume and cerebral blood flow on CT perfusion (Fig. 2a-c). The patient received stenting of the responsible artery to
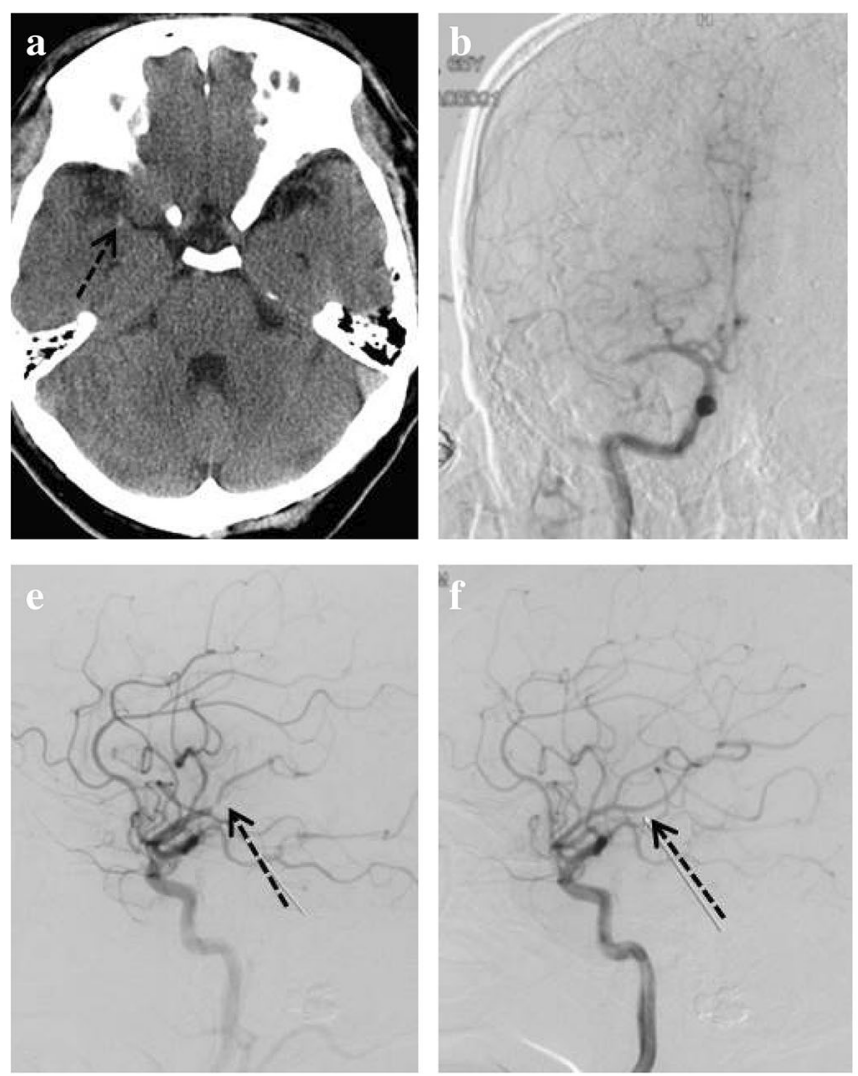

Fig 1 Images of case 1. a Non-contrast CT: a hyperdense right MCA (black arrow). b Cerebral angiography: occlusion of the M1 segment of right MCA from frontal image. c Cerebral angiography: occlusion of the M1 segment of right MCA from lateral image. d Cerebral angiography: spontaneous recanalization of the M1 segment of right MCA before
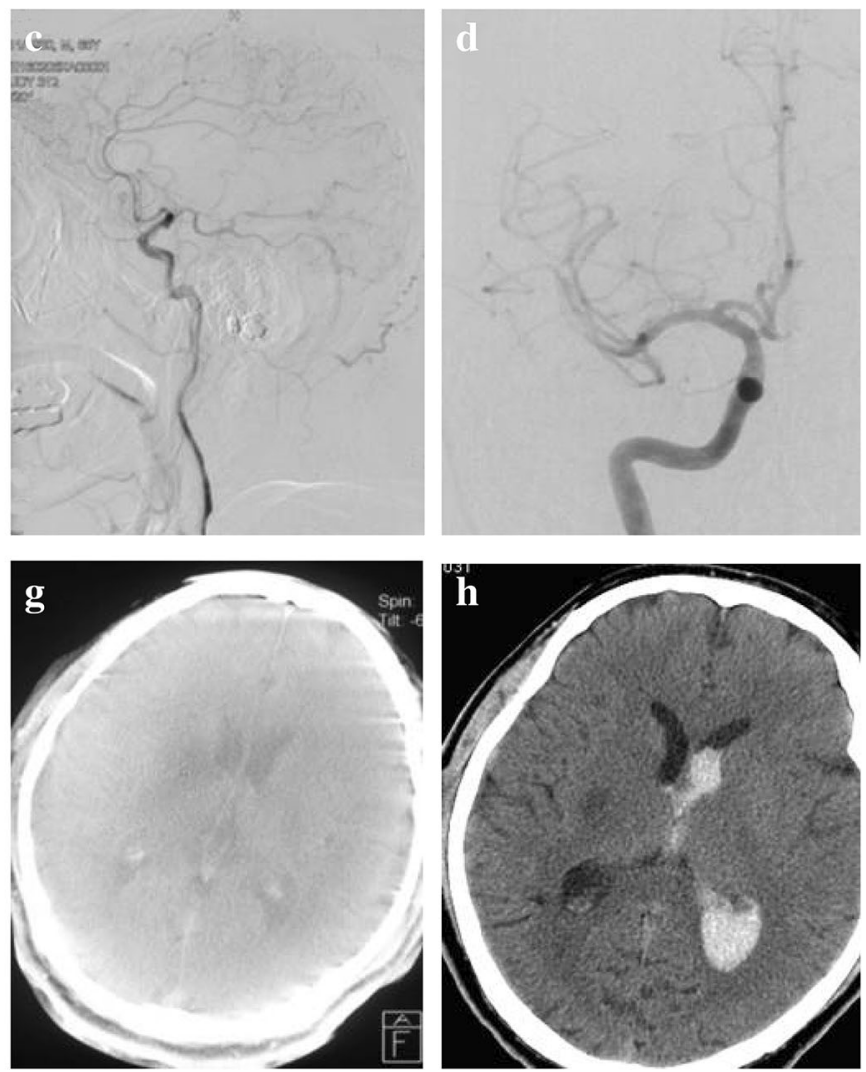

endovascular intervention. e Cerebral angiography: thrombus moving to MCA bifurcation 5 min later (black arrow). f Cerebral angiography: thrombus disappeared (black arrow) and complete recanalization of the right MCA. g Dyna-CT image: no hemorrhagic transformation. $\mathbf{h}$ Followup non-contrast $\mathrm{CT}$ at $24 \mathrm{~h}$ after IVT: right thalamus hemorrhage 

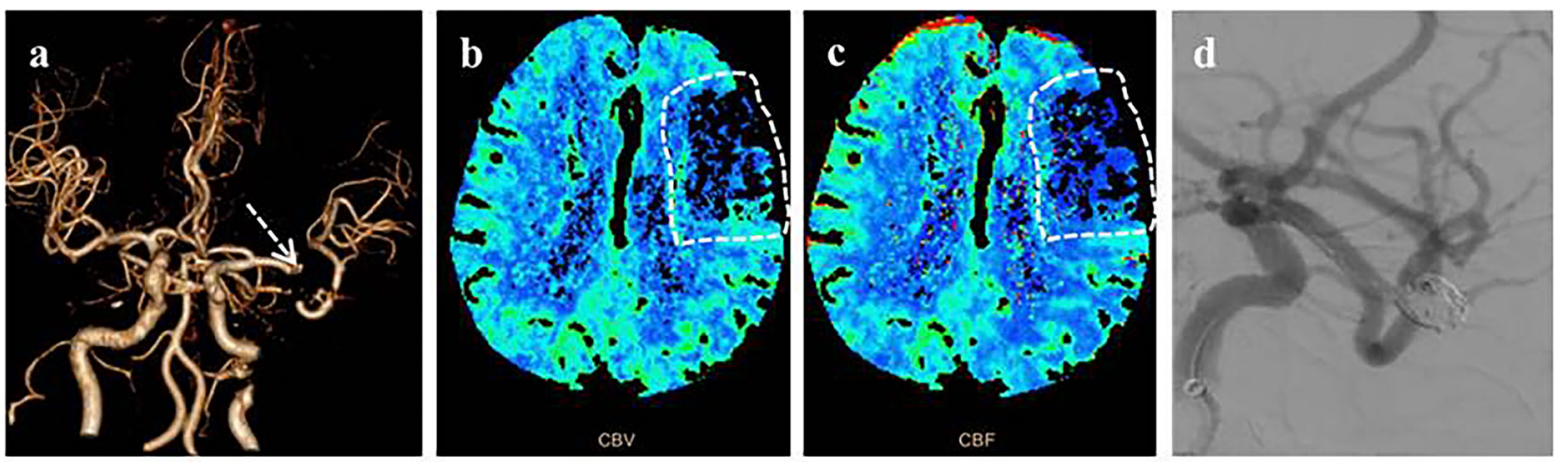

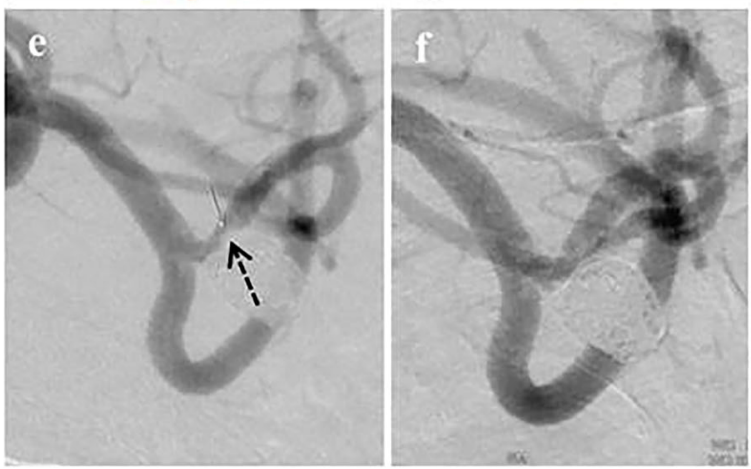

Fig 2. Images of case 2. a CT angiography: occlusion of the M1 upper branch of left MCA (white arrow). b CT perfusion: map of cerebral blood volume revealing low volume in the left frontal and parietal lobe (white dotted frame). c CT perfusion: map of cerebral blood flow revealing decreased flow in the left frontal and parietal lobe (white dotted frame). d Cerebral angiography: partial recanalization of the M1 upper branch

assist coil embolization of an unruptured bifurcation aneurysm 2 months ago (Fig. 2d) and took aspirin (Bayer, Germany) $100 \mathrm{mg} /$ day before stroke. As the patient was still within the thrombolytic time window, we administered $\mathrm{rtPA}(0.9 \mathrm{mg} / \mathrm{kg} \times 60 \mathrm{~kg})$ and performed DSA immediately. The DSA showed that the part of forward blood flow had recovered, but thrombus was still on the ostium of the artery (Fig. 2e). Then, IVT was continued and the occluded artery was recanalized to modified thrombolysis in cerebral infarction (mTICI) 3 (Fig. $2 \mathrm{f}$ and g) 15 min later without any endovascular intervention. Then, we stopped IVT when the total dose of rtPA was $45 \mathrm{mg}$ (5/6 standard dose, $0.75 \mathrm{mg} / \mathrm{kg}$ individually). But the symptom was not improved, and the NIHSS score was still 14. The DNT, door-to-puncture time, onset-toneedle time, and onset-to-reperfusion time were $35 \mathrm{~min}$, $63 \mathrm{~min}, 137 \mathrm{~min}$, and $182 \mathrm{~min}$, respectively. Non-contrast CT imaging showed hemorrhagic transformation (HT) with class 2 of the Heidelberg Bleeding Classification and PH2 of ECASS II [18] at $24 \mathrm{~h}$ (Fig. 2h). The location of HT was similar with the lower perfusion territory on the CT perfusion scan before IVT. Although the intracranial hemorrhage was absorbed within 1 week, clinical symptoms were not recovered, and the mRS was 4 at 90 days.
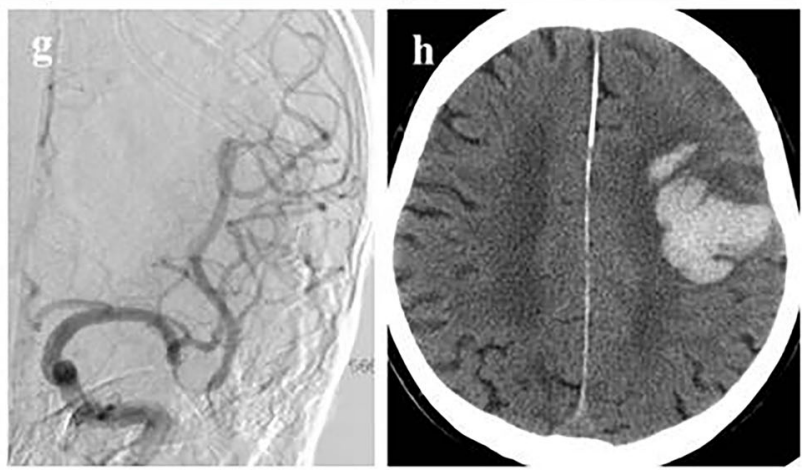

with recovering forward flow and coil embolization assisted with stent for unruptured bifurcation aneurysm. e Cerebral angiography: residual thrombus in M1 bifurcation (black arrow). f Cerebral angiography: thrombus disappeared completely. g Cerebral angiography: complete recanalization of the upper branch. $\mathbf{h}$ Follow-up non-contrast CT at $24 \mathrm{~h}$ after IVT: left frontal and parietal hematoma

\section{Discussion}

Here, we reported two cases of acute ischemic stroke with large vessel occlusions that both achieved complete recanalization after IVT. Then, IVT was terminated in advance, and dynamic surveillance by DSA was performed to achieve individual treatment. However, both of the cases were presented with hemorrhagic transformation. We analyzed the probable reasons and put forward thoughts from ourselves.

Both patients were Asian. The first patient didn't receive any antiplatelet or anticoagulation treatment before IVT, while the second patient received aspirin to prevent intra-stent thrombosis after stent-assisted embolization of aneurysm. Previous studies indicated that Asian populations had a higher prevalence of cerebral hemorrhage due to prior antiplatelet therapy, elderly patients, diabetes, and/or uncontrolled hypertension [19-22]. Therefore, in these populations, low-dose rtPA might be preferred, and we should think about terminating IVT in patients with high-risk of HT.

The recommended dose of intravenous rtPA was $0.9 \mathrm{mg} / \mathrm{kg}$ according to the NINDS trial, and this dose is still preferred nowadays [1]. Considering the risk of intracranial hemorrhage, some trials had attempted to determine the right rtPA dose that could balance both effectiveness and safety, but obtained different results [4-8]. The majority of the thrombus 
had been lysed before angiography in $11 \%$ of the cases in the endovascular therapy group of the EXTEND-IA trial [12], which indicated that IVT was necessary for AIS within thrombolytic time window. However, the thought whether IVT should be stopped when angiographic recanalization to mTICI 3 was unknown. In our cases, the occluded arteries achieved completed recanalization under the dynamic surveillance of DSA, and we stopped the IVT early. However, the strategy failed to prevent HT associated with IVT in both cases.

We hypothesized that individual sensitivity to rtPA was responsible to HT outside the infarcted region rather than the dose of rtPA in the first case. We could not imagine what would happen if we had administered the whole standarddose after complete recanalization was observed. Some studies showed that there was no correlation between the rtPA dose and HT [4, 23, 24]. However, there were opposite opinions $[18,25]$. Studies proved that HT was associated with blood-brain barrier disruption due to reperfusion, and this correlation was stronger in patients receiving endovascular treatment than in patients receiving intravenous rtPA [26, 27].

Comparing with rtPA, successful reperfusion might be the major factor that was responsible for HT in the second case. There was a significant low perfusion region before IVT from perfusion images both on the cerebral blood volume and cerebral blood flow, considered as core infarction. The following non-contrast $\mathrm{CT}$ imaging had proved that $\mathrm{HT}$ just occurred in the infarct region before IVT. According to the excluded criteria of the published trials, this case was not suitable for endovascular treatment because of less benefit from the vascular recanalization due to a large core infarct territory [13-15]. IVT for this case might be harmful because of large core infarction. However, large core infarction was not an exclusive criteria for rtPA, and we had to perform IVT for the case following the guideline. We have no answers on whether it was better to choose regular antiplatelet therapy rather than recanalization using IVT or endovascular treatment for patients with large core infarction. We do not know whether it would decrease the rate of HT after IVT on the base of multimodal imaging. At least, so far, IVT within $4.5 \mathrm{~h}$ is still the recommended standard treatment for AIS and not limited by multimodal imaging.

Magnetic resonance imaging and computed tomography angiography could help to detect cerebral infarcts and occlusion head-neck vessels, but both of them are not recommended as exclusive criteria for IVT [2, 28, 29]. Nevertheless, magnetic resonance perfusion and CT perfusion were recommended as inclusive criteria for MT or IVT for patients with uncertain time or long time from onset to arriving hospital [12, 14, 30-32]. A meta-analysis proved that patients with ischemic stroke within 4.5-9 h from stroke onset or wake-up stroke with salvageable brain tissue who were treated with rtPA achieved better functional outcomes than placebo group [32].
If we had performed MT directly without IVT for the first case, would we save the patient from HT? Although there were no randomized trials comparing MT after IVT with MT alone in thrombolytic time window, a meta-analysis indicated that patients with MT after IVT had better functional outcomes, lower mortality, higher rate of successful recanalization, and equal odds of symptomatic intracerebral hemorrhage compared with MT alone [33]. However, the post hoc analysis of ASTER trial showed that there were no significant differences between IVT before MT and MT alone in 90 days favorable functional outcome, successful reperfusion rate, or hemorrhagic complication rate, excepting 90 days mortality [34]. Randomized controlled trials should be performed to answer it, such as DIRECT-MT [35] trial, which had completed recruiting.

The major limitation of this study was the case reported with lower level evidence. Further work will be performed to strengthen the result.

\section{Conclusion}

IVT is still the standard treatment for AIS patients within $4.5 \mathrm{~h}$ from symptom onset. The individual dose of rtPA and treatment strategies for AIS-LVO on the era of MT still need more studies to demonstrate.

\section{Compliance with Ethical Standards}

Conflict of Interest The authors declare that they have no conflict of interest.

Ethical Approval For this type of study, formal consent was not required.

Open Access This article is distributed under the terms of the Creative Commons Attribution 4.0 International License (http:// creativecommons.org/licenses/by/4.0/), which permits unrestricted use, distribution, and reproduction in any medium, provided you give appropriate credit to the original author(s) and the source, provide a link to the Creative Commons license, and indicate if changes were made.

\section{References}

1. The National Institute of Neurological Disorders and Stroke rt-PA Stroke Study Group (1995) Tissue plasminogen activator for AIS. N Engl J Med 333(24):1581-1587

2. Powers WJ, Rabinstein AA, Ackerson T, Adeoye OM, Bambakidis NC, Becker K, Biller J, Brown M, Demaerschalk BM, Hoh B, Jauch EC, Kidwell CS, Leslie-Mazwi TM, Ovbiagele B, Scott PA, Sheth KN, Southerland AM, Summers DV, Tirschwell DL (2018) 2018 guidelines for the early management of patients with AIS: a guideline for healthcare professionals from the American 
Heart Association/American Stroke Association. Stroke 49(3):e46e110

3. Wahlgren N, Ahmed N, Dávalos A, Ford GA, Grond M, Hacke W, Hennerici WG, Kaste M, Kuelkens S, Larrue V, Lees KR, Roine RO, Soinne L, Toni D, Vanhooren G, SIVTS-MOST investigators (2007) Thrombolysis with alteplase for acute ischaemic stroke in the Safe Implementation of Thrombolysis in Stroke-Monitoring Study (SIVTS-MOST): an observational study. Lancet 369(9558): 275-282

4. Kim BJ, Han MK, Park TH, Park SS, Lee KB, Lee BC, Yu KH, Oh MS, Cha JK, Kim DH, Lee J, Lee SJ, Ko Y, Park JM, Kang K, Cho YJ, Hong KS, Kim JT, Choi JC, Kim DE, Shin DI, Kim WJ, Lee J, Lee JS, Yoon BS, Gorelick PB, Bae HJ (2015) Low- versus standard-dose alteplase for ischemic strokes within 4.5 hours: a comparative effectiveness and safety study. Stroke 46(9):25412548

5. Zhou XY, Wang XX, Collins ML, Davis ML, Yan B (2010) Efficacy and safety of different doses of intravenous tissue plasminogen activator in Chinese patients with ischemic stroke. J Clin Neurosci 17(8):988-992

6. Yamaguchi T, Mori E, Minematsu K, Nakagawara J, Hashi K, Saito I, Shinohara Y, Japan Alteplase Clinical Trial (J-ACT) Group (2006) Alteplase at $0.6 \mathrm{mg} / \mathrm{kg}$ for acute ischemic stroke within 3 hours of onset. Japan Alteplase Clinical Trial (J-ACT). Stroke 37(7):1810-1815

7. Anderson CS, Robinson T, Lindley RI, Arima H, Lavados PM, Lee TH, Broderick JP, Chen X, Chen G, Sharma VK, Kim JM, Thang NH, Cao Y, Parsons MW, Levi C, Huang Y, Olavarría VV, Demchuk AM, Bath PM, Donnan GA, Martins S, Pontes-Neto OM, Silva F, Ricci S, Roffe C, Pandian J, Billot L, Woodward M, Li Q, Wang X, Wang J, Chalmers J, ENCHANTED Investigators and Coordinators (2016) Low-dose versus standard-dose intravenous alteplase in acute ischemic stroke. N Engl J Med 374(24): 2313-2323

8. Liao XL, Wang YL, Pan YS, Wang CJ, Zhao XQ, Wang DZ, Liu LL, Wang YJ, Thrombolysis Implementation and Monitor of Acute Ischemic Stroke in China Investigators (2014) Standard-dose intravenous tissue-type plasminogen activator for stroke is better than low doses. Stroke 45(8):2354-2358

9. Saqqur M, Uchino K, Demchuk AM, Molina CA, Garami Z, Calleja S, Akhtar N, Orouk FO, Salam A, Shuaib A, Alexandrov AV, for CLOTBUST Investigators (2007) Site of Arterial Occlusion Identified by Transcranial Doppler Predicts the Response to Intravenous Thrombolysis for Stroke. Stroke 38(3):948-954

10. Bhatia R, Hill MD, Shobha N, Menon B, Bal S, Kochar P, Watson T, Goyal M, Demchuk AM (2010) Low rates of acute recanalization with intravenous recombinant tissue plasminogen activator in ischemic stroke: real-world experience and a call for action. Stroke 41(10):2254-2258

11. Berkhemer OA, Fransen PS, Beumer D, van den Berg LA, Lingsma HF, Yoo AJ, Schonewille WJ, Vos JA, Nederkoorn PJ, Wermer MJ, van Walderveen MA, Staals J, Hofmeijer J, van Oostayen JA, Lycklama à Nijeholt GJ, Boiten J, Brouwer PA, Emmer BJ, de Bruijn SF, van Dijk LC, Kappelle LJ, Lo RH, van Dijk EJ, de Vries J, de Kort PL, van Rooij WJ, van den Berg JS, van Hasselt BA, Aerden LA, Dallinga RJ, Visser MC, Bot JC, Vroomen PC, Eshghi O, Schreuder TH, Heijboer RJ, Keizer K, Tielbeek AV, den Hertog HM, Gerrits DG, van den Berg-Vos RM, Karas GB, Steyerberg EW, Flach HZ, Marquering HA, Sprengers ME, Jenniskens SF, Beenen LF, van den Berg R, Koudstaal PJ, van Zwam WH, Roos YB, van der Lugt A, van Oostenbrugge RJ, Majoie CB, Dippel DW, MR CLEAN Investigators (2015) A randomized trial of intraarterial treatment for acute ischemic stroke. $\mathrm{N}$ Engl J Med 372(1):11-20

12. Campbell BC, Mitchell PJ, Kleinig TJ, Dewey HM, Churilov L, Yassi N, Yan B, Dowling RJ, Parsons MW, Oxley TJ, Wu TY,
Brooks M, Simpson MA, Miteff F, Levi CR, Krause M, Harrington TJ, Faulder KC, Steinfort BS, Priglinger M, Ang T, Scroop R, Barber PA, McGuinness B, Wijeratne T, Phan TG, Chong W, Chandra RV, Bladin CF, Badve M, Rice H, de Villiers L, Ma H, Desmond PM, Donnan GA, Davis SM, EXTEND-IA Investigators (2015) Endovascular therapy for ischemic stroke with perfusion-imaging selection. N Engl J Med 372(11):1009-1018

13. Goyal M, Demchuk AM, Menon BK, Eesa M, Rempel JL, Thornton J, Roy D, Jovin TG, Willinsky RA, Sapkota BL, Dowlatshahi D, Frei DF, Kamal NR, Montanera WJ, Poppe AY, Ryckborst KJ, Silver FL, Shuaib A, Tampieri D, Williams D, Bang OY, Baxter BW, Burns PA, Choe H, Heo JH, Holmstedt CA, Jankowitz B, Kelly M, Linares G, Mandzia JL, Shankar J, Sohn SI, Swartz RH, Barber PA, Coutts SB, Smith EE, Morrish WF, Weill A, Subramaniam S, Mitha AP, Wong JH, Lowerison MW, Sajobi TT, Hill MD, Trial Investigators ESCAPE (2015) Randomized assessment of rapid endovascular treatment of ischemic stroke. N Engl J Med 372(11):1019-1030

14. Saver JL, Goyal M, Bonafe A, Diener HC, Levy EI, Pereira VW, Albers GW, Cognard C, Cohen DJ, Hacke W, Jansen O, Jovin TG, Mattle HP, Nogueira RG, Siddiqui AH, Yavagal DR, Baxter BW, Devlin TG, Lopes DK, Reddy VK, du Mesnil de Rochemont R, Singer OC, Jahan R, SWIFT PRIME Investigators (2015) Stentretriever thrombectomy after intravenous t-PA vs t-PA alone in stroke. N Engl J Med 372(24):285-2295

15. Jovin TG, Chamorro A, Cobo E, de Miquel MA, Molina CA, Rovira A, San RL, Serena J, Abilleira S, Ribó M, Millán M, Urra X, Cardona P, López-Cancio E, Tomasello A, Castaño C, Blasco J, Aja L, Dorado L, Quesada H, Rubiera M, Hernandez-Pérez M, Goyal M, Demchuk AM, von Kummer R, Gallofré M, Dávalos A, REVASCAT Trial Investigators (2015) Thrombectomy within 8 hours after symptom onset in ischemic stroke. N Engl J Med 372(24):2296-2306

16. Goyal M, Menon BK, van Zwam WH, Dippel DW, Mitchell PJ, Demchuk AM, Dávalos A, Majoie CB, van der Lugt A, de Miquel MA, Donnan GA, Roos YB, Bonafe A, Jahan R, Diener HC, van den Berg LA, Levy EI, Berkhemer OA, Pereira VM, Rempel J, Millán M, Davis SM, Roy D, Thornton J, Román LS, Ribó M, Beumer D, Stouch B, Brown S, Campbell BC, van Oostenbrugge RJ, Saver JL, Hill MD, Jovin TG, HERMES collaborators (2016) Endovascular thrombectomy after large-vessel ischaemic stroke: a meta-analysis of individual patient data from five randomised trials. Lancet 387(10029):1723-1731

17. von Kummer R, Broderick JP, Campbell BC, Demchuk A, Goyal M, Hill MD, Treurniet KM, Majoie CB, Marquering HA, Mazya MV, San Román L, Saver JL, Strbian D, Whiteley W, Hacke W (2015) The Heidelberg Bleeding Classification: classification of bleeding events after ischemic stroke and reperfusion therapy. Stroke 46(10):2981-2986

18. Hacke W, Kaste M, Fieschi C, von Kummer R, Davalos A, Meier D, Larrue V, Bluhmki E, Davis S, Donnan G, Schneider D, DiezTejedor E, Trouillas P (1998) Randomised double-blind placebocontrolled trial of thrombolytic therapy with intravenous alteplase in acute ischaemic stroke (ECASS II). Lancet 352(9136):12451251

19. Robinson TG, Wang X, Arima H, Bath PM, Billot L, Broderick JP, Demchuk AM, Donnan GA, Kim JS, Lavados PM, Lee TH, Lindley RI, Martins SCO, Olavarria VV, Pandian JD, Parsons MW, Pontes-Neto OM, Ricci S, Sato S, Sharma VK, Nguyen TH, Wang JG, Woodward M, Chalmers J, Anderson CS, ENCHANTED Investigators (2017) Low- versus standard-sose alteplase in patients on prior antiplatelet therapy: the ENCHANTED trial (enhanced control of hypertension and thrombolysis stroke study). Stroke 48(7):1877-1883

20. Chao AC, Hsu HY, Chung CP, Liu CH, Chen CH, Teng MM, Peng GS, Sheng WY, Hu HH, Taiwan Thrombolytic Therapy for Acute 
Ischemic Stroke (TTT-AIS) Study Group (2010) Outcomes of thrombolytic therapy for acute ischemic stroke in Chinese patients: the Taiwan Thrombolytic Therapy for Acute Ischemic Stroke (TTTAIS) study. Stroke 41(5):885-890

21. Pan YS, Chen QD, Liao XL, Zhao XQ, Wang CJ, Liu GF, Liu LP, Wang CX, Wang D, Wang YL, Wang YJ, TIMS-China Investigators (2015) Preexisting dual antiplatelet treatment increases the risk of post-thrombolysis intracranial hemorrhage in Chinese stroke patients. Neurol Res 2037(1):64-68

22. Sharma VK, Ng KW, Venketasubramanian N, Teoh HL, Chan BP (2012) Intravenous thrombolysis for acute ischemic stroke in Asia. Expert Rev Neurother 12(2):209-217

23. Sharma VK, Kawnayn G, Sarkar N (2013) Acute ischemic stroke: comparison of low-dose and standard-dose regimes of tissue plasminogen activator. Expert Rev Neurother 13(8):895-902

24. Yang J, Yu F, Liu H, An HD, Xiong R, Huang DY (2016) A retrospective study of thrombolysis with $0.6 \mathrm{mg} / \mathrm{kg}$ recombinant tissue plasminogen activator (rt-PA) in mild stroke. Sci Rep 6(1): 31344-31349

25. Morihara R, Kono S, Sato K, Hishikawa N, Ohta Y, Yamashita T, Deguchi K, Manabe Y, Takao Y, Kashihara K, Inoue S, Kiriyama H, Abe K (2016) Thrombolysis with low-dose tissue plasminogen activator 3-4.5 h after acute ischemic stroke in five hospital Groups in Japan. Transl Stroke Res 7(2):111-119

26. Latour LL, Kang DW, Ezzeddine MA, Chalela JA, Warach S (2004) Early blood-brain barrier disruption in human focal brain ischemia. Ann Neurol 56(4):468-477

27. Kim T, Koo J, Kim SH, Song IU, Chung SW, Lee KS (2018) Blood-brain barrier permeability assessed by perfusion computed tomography predicts hemorrhagic transformation in acute reperfusion therapy. Neurol Sci 39(9):1579-1584

28. Abdelrasoul AA, Elsebaie NA, Gamaleldin OA, Khalifa MH, Razek AAKA (2019) Imaging of brain infarctions: beyond the usual territories. J Comput Assist Tomogr 43(3):443-451

29. Abdel Razek AA, Denewer AT, Hegazy MA, Hafez MT (2014) Role of computed tomography angiography in the diagnosis of vascular stenosis in head and neck microvascular free flap reconstruction. Int J Oral Maxillofac Surg 43(7):811-815

30. Nogueira RG, Jadhav AP, Haussen DC, Bonafe A, Budzik RF, Bhuva P, Yavagal DR, Ribo M, Cognard C, Hanel RA, Sila CA, Hassan AE, Millan M, Levy EI, Mitchell P, Chen M, English JD, Shah QA, Silver FL, Pereira VM, Mehta BP, Baxter BW, Abraham MG, Cardona P, Veznedaroglu E, Hellinger FR, Feng L, Kirmani
JF, Lopes DK, Jankowitz BT, Frankel MR, Costalat V, Vora NA, Yoo AJ, Malik AM, Furlan AJ, Rubiera M, Aghaebrahim A, Olivot JM, Tekle WG, Shields R, Graves T, Lewis RJ, Smith WS, Liebeskind DS, Saver JL, Jovin TG, DAWN Trial Investigators (2018) Thrombectomy 6 to 24 hours after stroke with a mismatch between deficit and infarct. N Engl J Med 378(1):11-21

31. Albers GW, Marks MP, Kemp S, Christensen S, Tsai JP, OrtegaGutierrez S, McTaggart RA, Torbey MT, Kim-Tenser M, LeslieMazwi T, Sarraj A, Kasner SE, Ansari SA, Yeatts SD, Hamilton S, Mlynash M, Heit JJ, Zaharchuk G, Kim S, Carrozzella J, Palesch YY, Demchuk AM, Bammer R, Lavori PW, Broderick JP, Lansberg MG, DEFUSE 3 Investigators (2018) Thrombectomy for stroke at 6 to 16 hours with selection by perfusion imaging. N Engl J Med 378(8):708-718

32. BCV C, Ma H, Ringleb PA, Parsons MW, Churilov L, Bendszus M, Levi CR, Hsu C, Kleinig TJ, Fatar M, Leys D, Molina C, Wijeratne T, Curtze S, Dewey HM, Barber PA, Butcher KS, De Silva DA, Bladin CF, Yassi N, JAR P, Sharma G, Bivard A, Desmond PM, Schwab S, Schellinger PD, Yan B, Mitchell PJ, Serena J, Toni D, Thijs V, Hacke W, Davis SM, Donnan GA, EXTEND, CASS-4, and EPITHET Investigators (2019) Extending thrombolysis to 4.5$9 \mathrm{~h}$ and wake-up stroke using perfusion imaging: a systematic review and meta-analysis of individual patient data. Lancet 394(10193):139-147

33. Mistry EA, Mistry AM, Nakawah MO, Chitale RV, James RF, Volpi JJ, Fusco MR (2017) Mechanical thrombectomy outcomes with and without intravenous thrombolysis in stroke patients: a metaanalysis. Stroke 48(9):2450-2456

34. Gariel F, Lapergue B, Bourcier R, Berge J, Barreau X, Mazighi M, Kyheng M, Labreuche J, Fahed R, Blanc R, Gory B, Duhamel A, Saleme S, Costalat V, Bracard S, Desal H, Detraz L, Consoli A, Piotin M, Marnat G, Trial Investigators ASTER (2018) Mechanical thrombectomy outcomes with or without intravenous thrombolysis. Stroke 49(10):2383-2390

35. Direct Intra-arterial Thrombectomy in Order to Revascularize AIS Patients With Large Vessel Occlusion Efficiently in Chinese Tertiary Hospitals (DIRECT-MT). ClinicalTrials.gov Identifier: NCT03469206.

Publisher's note Springer Nature remains neutral with regard to jurisdictional claims in published maps and institutional affiliations. 